\title{
FIRST RECORDS OF SCALE DEFORMITIES IN SEVEN FRESHWATER FISH SPECIES (ACTINOPTERYGII: PERCIDAE AND CYPRINIDAE) COLLECTED FROM THREE PONDS IN THE CZECH REPUBLIC
}

\author{
Jitka RUTKAYOVÁ ${ }^{1}$, Laith JAWAD²*, Jana NEBESÁŘOVÁ ${ }^{3}$, Karel BENEŠ ${ }^{1}$, \\ Eva PETRÁŠKKOVÁ ${ }^{1}$, and Joacim NÄSLUND ${ }^{4}$ \\ ${ }^{1}$ University of South Bohemia, Faculty of Agriculture, Department of Animal Science, České Budějovice, \\ Czech Republic \\ ${ }^{2}$ Flat Bush, Manukau, Auckland, New Zealand \\ ${ }^{3}$ Laboratory of Electron Microscopy, The Institute of Parasitology, Biology centre Academy of Sciences \\ of the Czech Republic \\ ${ }^{4}$ Department of Biological and Environmental Sciences, University of Gothenburg, Gothenburg, Sweden
}

\begin{abstract}
Rutkayová J., Jawad L., Nebesářová J., Beneš K., Petrášková E., Näslund J. 2016. First records of scale deformities in seven freshwater fish species (Actinopterygii: Percidae and Cyprinidae) collected from three ponds in the Czech Republic. Acta Ichthyol. Piscat. 46 (3): 225-238.
\end{abstract}

Background. A wide range of morphological anomalies, including abnormalities in scale shape and structure, have been described from a large number of fish species worldwide. Quite often, such reports linked the observed abnormalities to the quality of aquatic environment. The presently reported study was initiated to explore and categorize the abnormalities found in the scales of seven freshwater fish species of Czech Republic: Ctenopharyngodon idella (Valenciennes, 1844); Gymnocephalus cernua (Linnaeus, 1758); Hypophthalmichthys molitrix (Valenciennes, 1844); Hypophthalmichthys nobilis (Richardson, 1845); Leuciscus idus (Linnaeus, 1758); Perca fluviatilis Linnaeus, 1758; and Sander lucioperca (Linnaeus, 1758). The observed abnormalities are discussed in the context of contaminated aquatic environments with the intention to understand the aetiology of the abnormalities

Materials and methods. Samples were collected at 3 sites (ponds) in the Czech Republic. In total, 10200 scales were collected, cleared in 1\% potassium hydroxide, and observed under a light microscope. Four variables were measured for each scale: anterior-posterior length (major axis, MAA), dorsal-ventral length (minor axis, MIA), diameter of the focus in the centre of the scale, number of radial lines (radii) starting from near focus, and the ratio of major to minor axes were calculated as a measure of scale shape.

Results. The anomalous scales, 63 in total, were collected from ten different body regions in seven species studied. They exhibited different shapes and sizes: 30 scales showed severe anomalies and 33 only slight ones. Based on the MAA : MIA ratio, the majority of the scales examined had a narrow to rectangular or broad to squarish shape. Elongated scales were only obtained from H. molitrix, H. nobilis, and C. idella. There were one square-shaped and 8 rectangular-shaped scales in G. cernua, 3 and 6 in P. fluviatilis, and 2 and 1 in S. lucioperca Conclusions. The presently reported cases of fish scale abnormalities should direct the future work on the relations between the state of the environment and fish health. Another interesting question to answer would be to determine whether or not the removal of abnormal scales would lead to replacement by either normal or abnormal scales.

Keywords: fish, scale abnormality, adverse environment, Cyprinidae, Percidae

\section{INTRODUCTION}

The freshwater ichthyofauna of the Czech Republic consists of 63 species, belonging to 16 families (Hanel 2003), and including at least 14 invasive species (Lusk et al. 2010a, 2010b). In our study we focused on seven fish species: the grass carp, Ctenopharyngodon idella (Valenciennes, 1844); the ruffe, Gymnocephalus cernua
(Linnaeus, 1758); the silver carp, Hypophthalmichthys molitrix (Valenciennes, 1844); the bighead carp, Hypophthalmichthys nobilis (Richardson, 1845); the ide, Leuciscus idus (Linnaeus, 1758); the European perch, Perca fluviatilis Linnaeus, 1758; and the pikeperch, Sander lucioperca (Linnaeus, 1758). Among the investigated species, three cyprinid species (silver carp,

* Correspondence: Laith A. Jawad, 4 Tin Turn Place, Flat Bush, Manukau, Auckland 2016, New Zealand, phone+64 9 2715165, e-mail: (LAJ) laith_jawad@hotmail.com, (JR)jitka.rutkay@centrum.cz,(JN)nebe@paru.cas.cz, (KB) benesk00@zf.jcu.cz, (EP)eva7petraskova@seznam.cz, (JN)joacim.naslund@gmail.com. 
bighead carp, and grass carp) are non-native to Europe, while a cyprinid species - ide, and three percid species (ruffe, European perch, and pike-perch) are native to Europe.

An important indicator of the effects of aquatic habitat degradation and pollution on fishes is a change in the occurrence of diseases and deformities in exposed populations (Sindermann 1979). In order to understand the aetiology of the abnormalities and how they vary with specific environmental and genetic factors, a sufficiently detailed description of specific abnormalities is required (Sun et al. 2009).

Fishes taken from contaminated waters may show morphological, histopathological, cellular, biochemical, organismic, or parasitic types of abnormalities that have been used as biomarkers of contamination (Sindermann 1979, Parente et al. 2004, Guilherme et al. 2008, Sun et al. 2009). A wide range of morphological anomalies has been described in a large number of fish species (Divanach et al. 1996, Jawad 2014, Jawad and Ibrahim 2014, Tyler et al. 2014, Jawad and Liu 2015), most of which have at some point been used for the assessment of contaminated aquatic environments. Compared with other types of biomarkers, externally visible morphological deformities are easy to recognize. They are, therefore, one of the quickest methods to assess the geographic scale of contaminations (Sun et al. 2009) in both fresh- or previously collected and preserved samples (Bengtsson et al. 1979).

Numerous authors (Blair 1942, Yamada 1961, Fouda 1979, Sire 1986, Bereiter-Han and Zylberberg 1993) have reported on the anatomy and developmental patterns of fish scales and on the relation between scale morphology, and genetic and environmental factors. Scale deformities have also been described in many fish species, e.g., the wavyband sole, Pseudaesopia japonica (Bleeker, 1866) (see Taki 1938); the red drum, Sciaenops ocellatus (Linnaeus, 1766) (see Günther 1941, 1945, 1948); the coitor croaker, Johnius coitor (Hamilton, 1822) (see Mookerjee 1948); the pinfish, Lagodon rhomboides (Linnaeus, 1766) (see Corrales et al. 2000); the Nile tilapia, Oreochromis niloticus (Linnaeus, 1758) (see Jawad 2005a); the Arabian shabout, Arabibarbus arabicus (Trewavas, 1941); Carasobarbus exulatus (Banister et Clarke, 1977); the Nile carp, Labeo niloticus (Linnaeus, 1758); and the Nile perch, Lates niloticus (Linnaeus, 1758) (see Jawad 2005b); Tripterygiidae (Jawad 2005a); Forsterygion capito (Jenyns, 1842) (see Jawad 2008); the greater lizardfish, Saurida tumbil (Bloch, 1795) (scales with curved sides, twin scales and anomalous circuli) (see Jawad and Al-Jufaili 2007); and the rohu, Labeo rohita (Hamilton, 1822) (see Jawad and Al-Mamry 2011). Our presently reported study, as earlier mentioned, covered seven freshwater fish species, economically important in central Europe. Moreover, no studies on scale anomalies of fishes from the Czech Republic have been published. Therefore, this is the first report on the subject for this country, describing a total of 63 cases of scale deformities in seven species of fish.

\section{MATERIALS AND METHODS}

Samples were collected at 3 sites (ponds) in the Czech Republic:Vrkoč $\left(48.933^{\circ} \mathrm{N}, 16.557^{\circ} \mathrm{E}\right)$ (Hypophthalmichthys molitrix, Hypophthalmichthys nobilis, Ctenopharyngodon idella, Leuciscus idus), Svět $\left(48.994^{\circ} \mathrm{N}, 14.750^{\circ} \mathrm{E}\right)$ (Sander lucioperca), and Opatovický $\left(48.982^{\circ} \mathrm{N}, 14.769^{\circ} \mathrm{E}\right)$ (Gymnocephalus cernua, Perca fluviatilis) during the period from 24 April to 16 October 2014. The specimens were collected with a seine net. Total length (TL) was measured to the nearest $0.1 \mathrm{~mm}$ from the anterior tip of the snout to the end of the pinched caudal fin. Scales from 10 specimens per species were examined: $H$. molitrix (250), H. nobilis (340), C. idella (234), L. idus (243), G. cernua (210), P. Aluviatilis (215), and S. lucioperca (220). ANOVA tests were used to compare measurements of normal scales with those of anomalous scales from the same body regions (Table 1). Scales were observed through light microscopy following the methods of Takagi (1953), Roberts (1993), Lippitsch (1993), Kuusipalo (1998, 2000), Jawad (2005a, 2005b) and Jawad and AlJufaili (2007). For the purpose of this study, the fish body was divided into eight regions (Fig. 1). In addition, scales from anterior-, middle-, and posterior parts of the lateral line were sampled to study their variation in shape and size (Fig. 2). In total, 10200 scales were removed with a forceps from each region of the left side of a specimen and then cleared in a solution of $1 \%$ potassium hydroxide. The number of abnormal scales ranged from 4 to 6 in each region. Remaining adhering tissue was removed under a dissecting microscope. Scales were stained with Alizarin Red S for 2-3 days and afterwards mounted between glass slides. Four variables were measured for each scale: the anterior-posterior length (major axis, MAA), the dorsalventral length (minor axis, MIA), the diameter of the focus in the centre of the scale, and the number of radial lines (radii) starting near the focus. The ratio of major to minor axes was calculated as a measure of the scale shape. A scale was considered square-shape when MAA : MIA = 1; an elongated or tall one when MAA : MIA $>1$; and a rectangular or broad one when MAA : MIA $<1$. In this study, abnormal scales were considered common when obtained from three or more specimens, otherwise they were regarded as uncommon. The age of the specimens was determined by counting the annuli on the scales under light microscope. Analysis of variance was applied to differentiate between normal and abnormal scales.

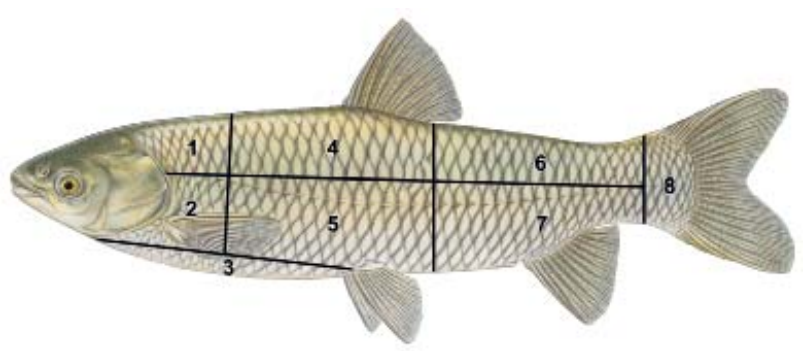

Fig. 1. Areas where scales were removed from left side of fish; The fish image - courtesy of Lenka Vybíralová, Praha, Czech Republic 
Table 1

Biodata of normal scales from seven freshwater fish species collected from Ponds Vrkoč, Svět, and Opatovický, Czech Republic

\begin{tabular}{|c|c|c|c|c|c|c|}
\hline Species & $\begin{array}{c}\text { Range fish } \\
\text { length }[\mathrm{mm}]\end{array}$ & $\begin{array}{l}\text { Fish body } \\
\text { region }\end{array}$ & MAA & MIA & MAA : MIA & $\begin{array}{l}\text { Range of No. of } \\
\text { radial lines }\end{array}$ \\
\hline \multirow[t]{5}{*}{ Hypophthalmichthys nobilis } & $442.3-447.2$ & R5 & $0.6-0.7$ & $0.5-0.6$ & $1.3-2.9$ & $2 / 1-3 / 2$ \\
\hline & $442.3-447.2$ & R6 & $0.5-0.6$ & $0.4-0.45$ & $1.4-1.5$ & $3 / 5-4 / 6$ \\
\hline & $442.3-447.2$ & R7 & $0.6-0.8$ & $0.5-0.7$ & $1.1-1.2$ & $3 / 1-4 / 2$ \\
\hline & & R9 & $0.7-0.85$ & $0.5-0.7$ & $1.2-1.3$ & 0 \\
\hline & & $\mathrm{R} 10$ & $0.6-0.8$ & $0.5-0.7$ & $1.1-1.2$ & 0 \\
\hline Ctenopharyngodon idella & 200.9-285.1 & R5 & $10.2-12.5$ & $7.8-9.2$ & $1.2-1.3$ & $5 / 3-7 / 4$ \\
\hline \multirow[t]{7}{*}{ Gymnocephalus cernua } & $109.7-114.5$ & $\mathrm{R} 1$ & $1.5-1.9$ & $1.4-1.7$ & $1.2-1.3$ & $7 / 1-9 / 3$ \\
\hline & & $\mathrm{R} 2$ & $2.4-2.9$ & $2.7-2.8$ & $0.9-1.1$ & $7 / 1-9 / 2$ \\
\hline & & $\mathrm{R} 4$ & $1.7-2.0$ & $1.7-1.9$ & $1.0-2.1$ & $7 / 2-9 / 4$ \\
\hline & & R5 & $2.7-2.9$ & $2.8-3.0$ & $0.9-1.2$ & $8 / 3-9 / 5$ \\
\hline & & R6 & $1.6-1.8$ & $1.2-1.6$ & $1.4-1.5$ & $7 / 2-9 / 4$ \\
\hline & & R7 & $2.3-2.6$ & $2.4-2.8$ & $1.1-1.2$ & $8 / 3-9 / 5$ \\
\hline & & $\mathrm{R} 8$ & $1.9-2.1$ & $1.8-2.0$ & $1.1-1.3$ & $9 / 3-9 / 5$ \\
\hline \multirow[t]{2}{*}{ Hypophthalmichthys molitrix } & $383.8-411.3$ & $\mathrm{R} 3$ & $7.7-8.2$ & $5.6-6.3$ & $1.3-1.4$ & $1 / 2-3 / 2$ \\
\hline & & R9 & $9.4-10.2$ & $5.0-7.4$ & $1.8-1.4$ & 0 \\
\hline Leuciscus idus & $202.7-247.2$ & $\mathrm{R} 8$ & $4.8-6.2$ & $3.9-5.2$ & $1.2-1.3$ & $7 / 3-9 / 4$ \\
\hline \multirow[t]{8}{*}{ Perca fluviatilis } & $154.1-233.6$ & $\mathrm{R} 1$ & $1.7-1.9$ & $1.9-2.2$ & $0.9-1.1$ & $6 / 1-8 / 2$ \\
\hline & & $\mathrm{R} 2$ & $3.4-3.9$ & $3.6-4.2$ & $0.9-1.2$ & $6 / 1-8 / 2$ \\
\hline & & $\mathrm{R} 3$ & $1.8-2.0$ & $1.9-2.3$ & $0.9-1.1$ & $6 / 1-7 / 2$ \\
\hline & & R5 & $3.0-3.5$ & $3.4-3.8$ & $0.8-0.9$ & $6 / 1-7 / 2$ \\
\hline & & R6 & $2.2-2.8$ & $1.8-2.2$ & $1.2-1.3$ & $4 / 1-5 / 2$ \\
\hline & & R7 & $3.0-3.6$ & $2.8-3.0$ & $1.1-1.2$ & $4 / 2-5 / 2$ \\
\hline & & $\mathrm{R} 8$ & $2.1-2.5$ & $1.9-2.5$ & $0.9-1.0$ & $4 / 1-5 / 2$ \\
\hline & & $\mathrm{R} 10$ & $2.6-2.9$ & $2.5-2.8$ & $1.0-1.1$ & $6 / 0-6 / 0$ \\
\hline \multirow[t]{5}{*}{ Sander lucioperca } & $88.9-129.2$ & $\mathrm{R} 4$ & $0.12-0.16$ & $0.13-0.18$ & $0.9-1.0$ & $8 / 1-9 / 2$ \\
\hline & & R5 & $0.22-0.31$ & $0.21-0.34$ & $1.0-1.1$ & $8 / 1-9 / 2$ \\
\hline & & R6 & $0.20-0.28$ & $0.11-0.20$ & $1.0-1.4$ & $8 / 1-8 / 2$ \\
\hline & & R7 & $0.12-0.16$ & $0.12-0.17$ & $1.0-1.2$ & $9 / 1-9 / 2$ \\
\hline & & $\mathrm{R} 8$ & $0.12-0.16$ & $0.12-0.17$ & $1.0-1.1$ & $9 / 1-9 / 2$ \\
\hline
\end{tabular}

MAA $=$ major axis (range), MIA $=$ minor axis (range), MAA : MIA $=$ major- and minor axes ratio.

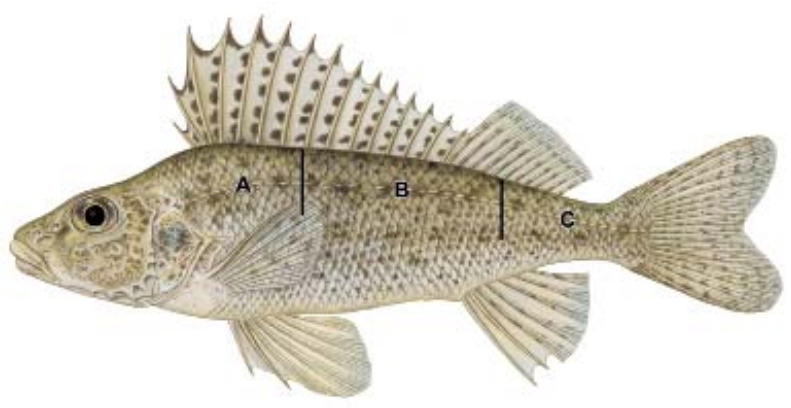

Fig. 2. Three areas where scales of lateral line were removed from the left side of fish; The fish image - courtesy of Lenka Vybíralová, Praha, Czech Republic

\section{RESULTS}

The age of the specimens varied between 1 and $4^{+}$. Specifically, the age of Gymnocephalus cernua ranged from $1^{+}$to $2^{+}$, that of Sander lucioperca-from $1^{+}$to 3 , that of Hypophthalmichthys molitrix-from $2^{+}$to $3^{+}$, that of Leuciscus idus-3-4, and the age of Ctenopharyngodon idella and Hypophthalmichthys nobilis-from 3 to $3^{+}$years and Perca fluviatilis $2^{+}$to $3^{+}$. Of the 63 abnormal scales examined, severe and slight abnormalities were found in a total of 30 and 33 scales, respectively. The anomalous scales were collected from 1-10 body regions. The frequency distribution of abnormal scales among species was as follows: H. nobilis, 7 ; C. idella, 1 ; G. cernua, $18 ; H$. molitrix, 2; L. idus, 1; P. fluviatilis, 26; and S. lucioperca, 7. Perca fluviatilis exhibited the highest number of both slightly and severely abnormal scales. Abnormal lateral line scales were observed in $H$. molitrix (1), H. nobilis (4), and P. fluviatilis (1) (Table 2). Analysis of variance showed that the morphometrics differed between the normal and abnormal scales obtained from the species studied $(P<0.001)$.

Based on the MAA : MIA ratio, the majority of the scales examined had a narrow to rectangular or broad to squarish shape. Elongated scales were only obtained from H. molitrix, H. nobilis, and C. idella. There were: 1 squareshaped and 8 rectangular-shaped scales in G. cernua, 3 and 6 in P. fluviatilis, and 2 and 1 in S. lucioperca (Fig. 3).

Four fields were recognized in the scales of the seven fish species studied: one rostral, two lateral, and one caudal. Scale dimensions, total scale width, and anterior 
Table 2

Biodata of abnormal scales from seven freshwater fish species collected from ponds: Vrkoč, Svět, and Opatovický, Czech Republic

\begin{tabular}{|c|c|c|c|c|c|c|c|c|}
\hline Species & $\begin{array}{c}\text { Fish } \\
\text { length } \\
{[\mathrm{mm}]}\end{array}$ & $\begin{array}{l}\text { Fish } \\
\text { body } \\
\text { region }\end{array}$ & $\begin{array}{c}\text { Type of } \\
\text { abnormality }\end{array}$ & Type of scale & MAA & MIA & $\begin{array}{r}\text { MAA } \\
\text { MIA }\end{array}$ & $\begin{array}{c}\text { No. of } \\
\text { radial } \\
\text { lines }\end{array}$ \\
\hline Hypophthalmichthys & 442.3 & R5 & Slight & Non-regenerated body scale & 0.58 & 0.43 & 1.35 & $3 / 1$ \\
\hline \multirow[t]{6}{*}{ nobilis } & 442.3 & R6 & Slight & Non-regenerated body scale & 0.53 & 0.46 & 1.15 & $0 / 3$ \\
\hline & 442.3 & R9 & Slight & Lateral line scale & 0.54 & 0.32 & 1.7 & 0 \\
\hline & 442.3 & R9 & Severe & Lateral line scale & 0.51 & 0.49 & 1.04 & 0 \\
\hline & 442.3 & R9 & Severe & Lateral line scale & 0.49 & 0.32 & 1.5 & 0 \\
\hline & 442.3 & $\mathrm{R} 10$ & Severe & Lateral line scale & 0.59 & 0.51 & 1.12 & 0 \\
\hline & 446.9 & R7 & Slight & Non-regenerated body scale & 0.59 & 0.47 & 1.3 & $1 / 6$ \\
\hline $\begin{array}{l}\text { Ctenopharyngodon } \\
\text { idella }\end{array}$ & 285.1 & R5 & Slight & Non-regenerated body scale & 5.3 & 5.0 & 1.1 & $10 / 4$ \\
\hline \multirow[t]{19}{*}{ Gymnocephalus cernua } & 109.7 & $\mathrm{R} 1$ & Slight & Non-regenerated body scale & 2.2 & 2.1 & 1.1 & $8 / 1$ \\
\hline & 109.7 & $\mathrm{R} 2$ & Slight & Non-regenerated body scale & 2.6 & 1.7 & 1.5 & $7 / 1$ \\
\hline & 109.7 & R4 & Slight & Non-regenerated body scale & 1.7 & 1.5 & 1.1 & $4 / 1$ \\
\hline & 109.7 & $\mathrm{R} 4$ & Slight & Non-regenerated body scale & 1.9 & 1.7 & 1.1 & $8 / 1$ \\
\hline & 109.7 & R5 & Severe & Regenerated body scale & 2.8 & 3.1 & 0.9 & $0 / 10$ \\
\hline & 109.7 & R5 & Severe & Regenerated body scale & 2.5 & 2.9 & 0.8 & $0 / 12$ \\
\hline & 109.7 & R6 & Severe & Regenerated body scale & 1.1 & 0.9 & 1.2 & $0 / 7$ \\
\hline & 109.7 & $\mathrm{R} 8$ & Severe & Regenerated body scale & 0.3 & 0.3 & 1 & $0 / 10$ \\
\hline & 114.6 & $\mathrm{R} 1$ & Slight & Non-regenerated body scale & 1.3 & 1.4 & 0.9 & $7 / 1$ \\
\hline & 114.6 & $\mathrm{R} 1$ & Slight & Non-regenerated body scale & 1.3 & 1.6 & 0.8 & $6 / 3$ \\
\hline & 114.6 & $\mathrm{R} 1$ & Slight & Non-regenerated body scale & 1.6 & 1.8 & 0.9 & $7 / 3$ \\
\hline & 114.6 & $\mathrm{R} 4$ & Slight & Non-regenerated body scale & 1.9 & 2.2 & 0.9 & $8 / 1$ \\
\hline & 114.6 & R6 & Slight & Regenerated body scale & 1.9 & 1.5 & 1.3 & $0 / 14$ \\
\hline & 114.6 & R6 & Slight & Regenerated body scale & 1.9 & 1.5 & 1.3 & $0 / 16$ \\
\hline & 114.6 & R6 & Slight & Non-regenerated body scale & 2.0 & 1.6 & 1.3 & $7 / 0$ \\
\hline & 114.6 & R7 & Slight & Non-regenerated body scale & 2.1 & 1.9 & 1.1 & $8 / 3$ \\
\hline & 114.6 & $\mathrm{R} 2$ & Severe & Regenerated body scale & 1.7 & 2.8 & 0.6 & $0 / 17$ \\
\hline & 114.6 & R5 & Severe & Non-regenerated body scale & 2.7 & 1.4 & 1.9 & $9 / 8$ \\
\hline & 114.6 & $\mathrm{R} 5$ & Severe & Non-regenerated body scale & 2.6 & 3.2 & 0.8 & $8 / 8$ \\
\hline \multirow{2}{*}{$\begin{array}{l}\text { Hypophthalmichthys } \\
\text { molitrix }\end{array}$} & 386.1 & R3 & Slight & Non-regenerated body scale & 7.6 & 6.0 & 1.3 & $1 / 1$ \\
\hline & 411.3 & R9 & Severe & Lateral line scale & 9.3 & 6.3 & 1.5 & 0 \\
\hline Leuciscus idus & 218.0 & $\mathrm{R} 8$ & Slight & Non-regenerated body scale & 1.1 & 5.4 & 0.2 & $9 / 0$ \\
\hline \multirow{26}{*}{ Perca fluviatilis } & 154.1 & R6 & Slight & Regenerated body scale & 1.7 & 1.6 & 1.1 & $3 / 1$ \\
\hline & 154.1 & $\mathrm{R} 8$ & Slight & Non-regenerated body scale & 1.4 & 1.1 & 1.3 & $3 / 0$ \\
\hline & 154.1 & $\mathrm{R} 8$ & Slight & Regenerated body scale & 1.7 & 1.4 & 1.2 & $0 / 3$ \\
\hline & 219.2 & $\mathrm{R} 1$ & Slight & Non-regenerated body scale & 3.1 & 3.5 & 0.9 & $8 / 0$ \\
\hline & 219.2 & R5 & Slight & Regenerated body scale & 6.3 & 6.2 & 1.0 & $0 / 7$ \\
\hline & 219.2 & R6 & Slight & Regenerated body scale & 3.8 & 2.8 & 1.4 & $0 / 4$ \\
\hline & 219.2 & R6 & Slight & Non-regenerated body scale & 3.0 & 2.7 & 1.1 & $5 / 0$ \\
\hline & 219.2 & R7 & Slight & Regenerated body scale & 5.0 & 4.5 & 1.1 & $0 / 4$ \\
\hline & 219.2 & $\mathrm{R} 8$ & Slight & Regenerated body scale & 2.4 & 1.9 & 1.3 & $3 / 1$ \\
\hline & 219.2 & $\mathrm{R} 8$ & Slight & Non-regenerated body scale & 2.2 & 1.8 & 1.2 & $3 / 1$ \\
\hline & 219.2 & $\mathrm{R} 1$ & Severe & Non-regenerated body scale & 3.3 & 4.2 & 0.8 & $0 / 5$ \\
\hline & 219.2 & $\mathrm{R} 1$ & Severe & Regenerated body scale & 3.3 & 3.3 & 1.0 & $0 / 7$ \\
\hline & 219.2 & $\mathrm{R} 2$ & Severe & Non-regenerated body scale & 5.6 & 6.9 & 0.8 & $7 / 3$ \\
\hline & 219.2 & $\mathrm{R} 3$ & Severe & Regenerated body scale & 3.6 & 3.3 & 1.1 & $0 / 3$ \\
\hline & 219.2 & $\mathrm{R} 3$ & Severe & Regenerated body scale & 4.3 & 3.2 & 1.3 & $0 / 5$ \\
\hline & 219.2 & R3 & Severe & Regenerated body scale & 3.3 & 2.7 & 1.2 & $0 / 5$ \\
\hline & 219.2 & R3 & Severe & Non-regenerated body scale & 4.1 & 3.3 & 1.2 & $6 / 0$ \\
\hline & 219.2 & $\mathrm{R} 8$ & Severe & Regenerated body scale & 1.8 & 1.4 & 1.3 & $0 / 3$ \\
\hline & 219.2 & $\mathrm{R} 10$ & Severe & Lateral line scale & 3.4 & 3.1 & 1.1 & $6 / 0$ \\
\hline & 233.6 & $\mathrm{R} 2$ & Slight & Non-regenerated body scale & 3.9 & 2.7 & 1.4 & $4 / 0$ \\
\hline & 233.6 & R3 & Slight & Non-regenerated body scale & 4.8 & 2.7 & 1.8 & $3 / 0$ \\
\hline & 233.6 & R7 & Slight & Regenerated body scale & 3.3 & 3.8 & 0.9 & 0 \\
\hline & 233.6 & R1 & Severe & Non-regenerated body scale & 4.0 & 4.1 & 1.0 & 0 \\
\hline & 233.6 & R1 & Severe & Regenerated body scale & 3.1 & 4.9 & 0.6 & 0 \\
\hline & 233.6 & R6 & Severe & Non-regenerated body scale & 2.6 & 2.9 & 0.9 & $0 / 10$ \\
\hline & 233.6 & $\mathrm{R} 8$ & Severe & Non-regenerated body scale & 2.2 & 1.5 & 1.5 & $0 / 2$ \\
\hline
\end{tabular}


Table 2 cont.

\begin{tabular}{ccccccccc}
\hline \multirow{2}{*}{ Species } & $\begin{array}{c}\text { Fish } \\
\text { length } \\
{[\mathrm{mm}]}\end{array}$ & $\begin{array}{c}\text { Fish } \\
\text { body } \\
\text { region }\end{array}$ & $\begin{array}{c}\text { Type of } \\
\text { abnormality }\end{array}$ & Type of scale & MAA & MIA & $\begin{array}{c}\text { MAA : } \\
\text { MIA }\end{array}$ & $\begin{array}{c}\text { No. of } \\
\text { radial } \\
\text { lines }\end{array}$ \\
\hline Sander lucioperca & 88.8 & R5 & Severe & Regenerated body scale & 0.2 & 0.2 & 1.0 & $0 / 10$ \\
& 88.8 & R6 & Severe & Regenerated body scale & 0.1 & 0.04 & 2.5 & $0 / 5$ \\
& 88.8 & R7 & Severe & Regenerated body scale & 0.2 & 0.1 & 2 & $5 / 2$ \\
& 120.9 & R7 & Severe & Regenerated body scale & 0.1 & 0.1 & 1.0 & $0 / 7$ \\
& 120.9 & R8 & Severe & Regenerated body scale & 0.08 & 0.07 & 1.1 & 0 \\
& 124.3 & R8 & Slight & Regenerated body scale & 0.12 & 0.10 & 1.2 & $0 / 7$ \\
& 125.2 & R4 & Severe & Non-regenerated body scale & 0.1 & 0.2 & 0.5 & $8 / 0$ \\
\hline
\end{tabular}

MAA $=$ major axis $($ range $)$, MIA $=$ minor axis $($ range $)$, MAA $:$ MIA $=$ major- and minor axes ratio.
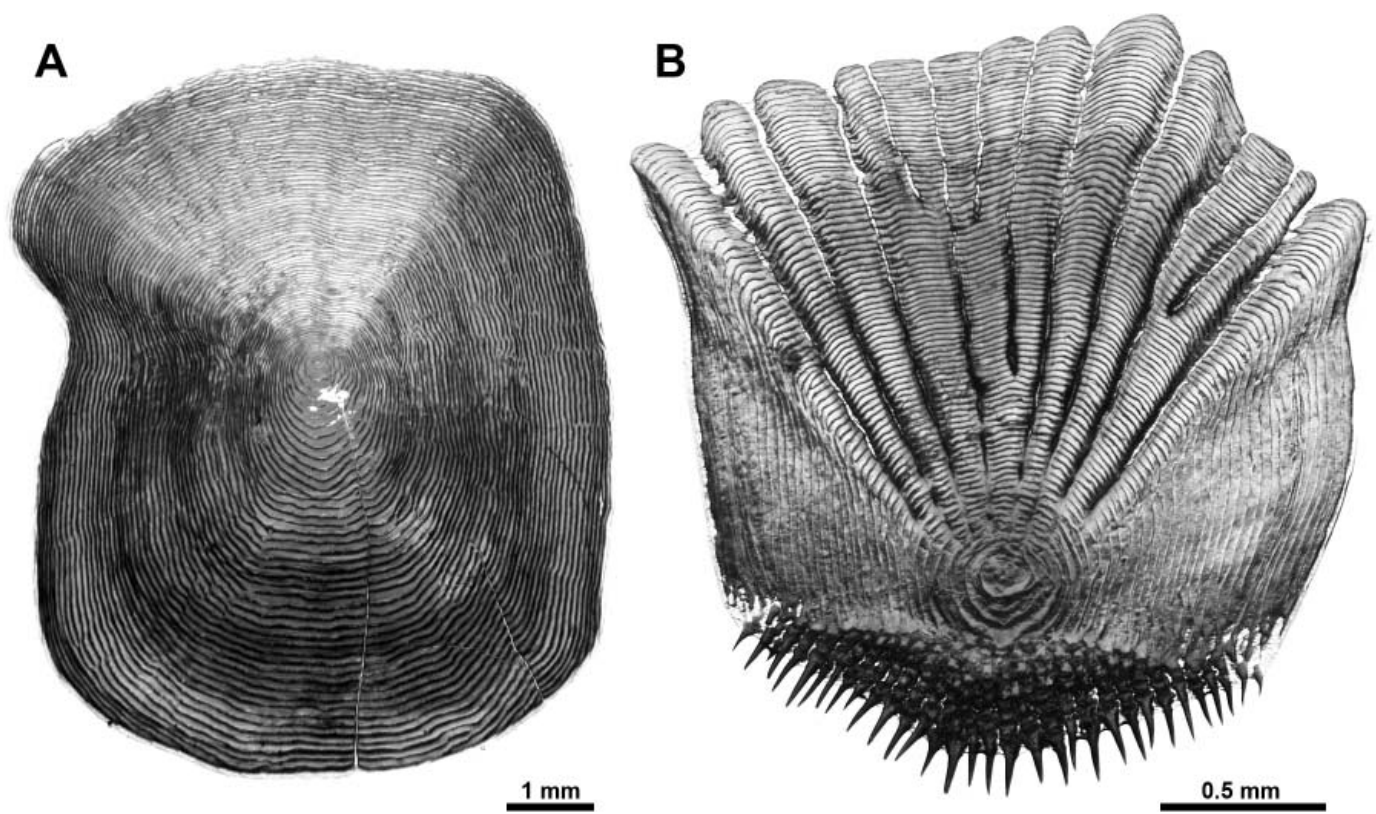

Fig. 3. Shapes of the scales: rectangular (A) and squarish (B)

radius from the focus to the anterior edge of the scale were chosen to give an indication of the scale size (Fig. 4).

Deformed scales varied according to the body region, occurring mostly in $\mathrm{R} 8$ (L. idus, P. fluviatilis, and $S$. lucioperca) and R9 (H. molitrix and H. nobilis). Ctenopharyngodon idella and L. idus showed anomalous scales only in R5 an R8, respectively. Gymnocephalus cernua had the highest number of body regions with abnormal scales (R1, R4, R5). Two regions were observed in H. molitrix (R3, R9), P. fluviatilis (R6, R8), and S. lucioperca (R7, R8).

Description of scale deformities. Two categories of scale deformities were defined in the body scales, based on the complexity of the case. The slight deformity occurred in one region of the scale only and the deformity is not complicated. The severe anomaly occurred in more than one region of the scale, heavily deformed in comparison with the normal shape. In the slight deformity category, there are either common or uncommon cases of scale anomalies.

The common cases included:

- Abnormalities on the dorsal and ventral sides of the scale. Within this group, the sides were either emarginate, curved, constricted, indented, or straight.
These various types of anomaly were observed in H. molitrix, H. nobilis, G. cernua, and P. fluviatilis (Figs. 5A-5E)

- Displacement of the anterior and posterior ends of the scale. Displacement was observed either with or without the displacement of the focus, and either dorsally or ventrally. These anomalies were observed in C. idella, G. cernua, and P. fluviatilis (Figs. 5F-5H).

- Deformity of the lobes on the anterior side of the scales. This abnormality included differences in either the length or absence of scale lobes, and was observed in G. cernua, P. fluviatilis, and S. lucioperca (Fig. 5I).

- Anomalies in scale circuli. Circuli deformities were observed in both the dorsal and ventral lateral fields and around the focus. They included irregularity in shape, distance to each other and undulation. These abnormalities were noted in G. cernua, H. molitrix, and S. lucioperca (Fig. 5J).

The uncommon cases of scale abnormalities included:

- Deformities of ctenii and the ctenii area. Ctenii were observed to be either directed downward, joined together, irregular in shape, or absent from the area anterior to the ctenii line. In some cases, the area 

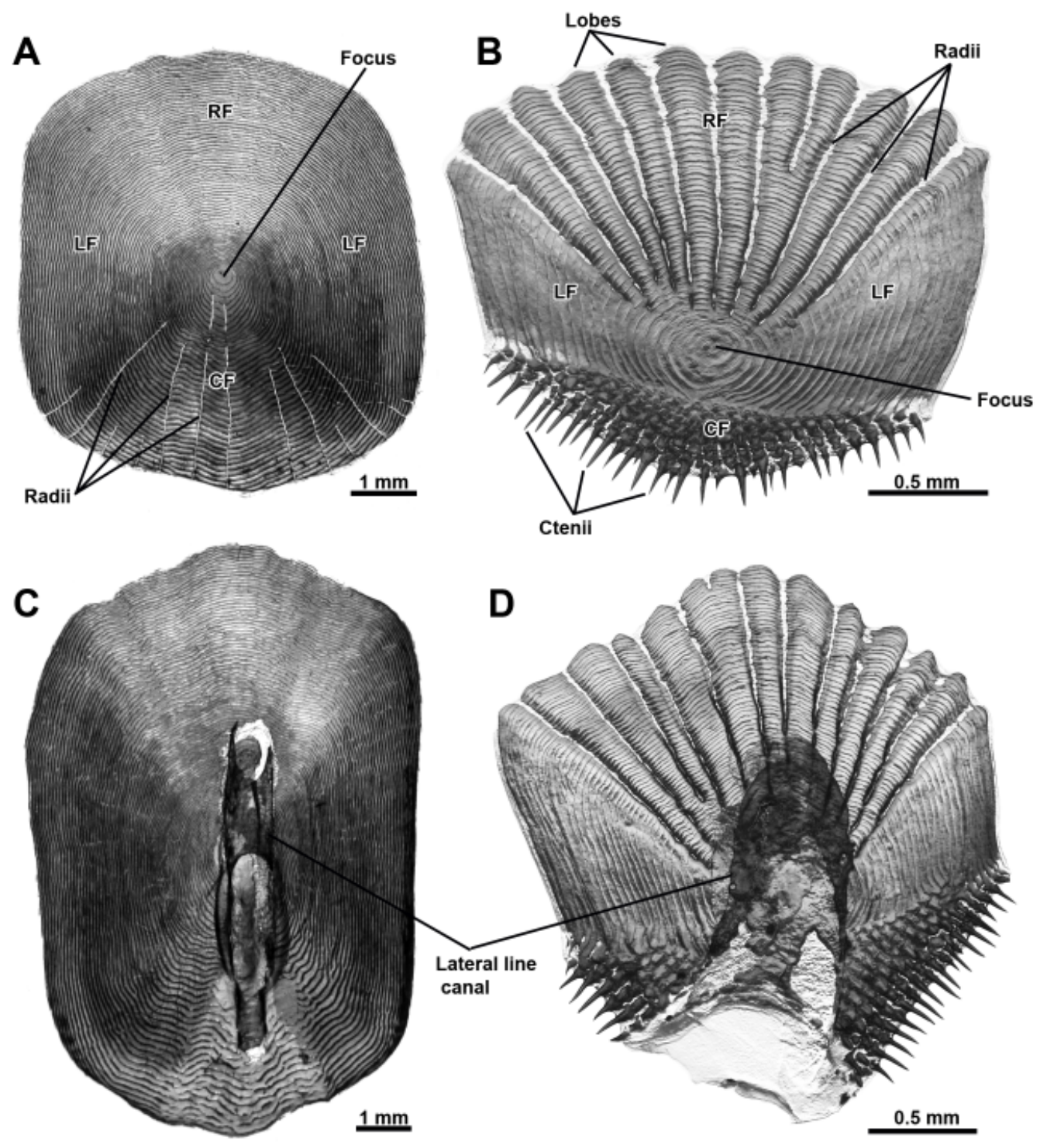

Fig. 4. Principal scale fields: Body scale of Hypophthalmichthys molitrix (A); Body scale of Gymnocephalus cernua (B); (C) Lateral line scale of Hypophthalmichthys molitrix (C); Lateral line scale of Gymnocephalus cernua (D); RF = rostral field, $\mathrm{LF}=$ lateral field, $\mathrm{CF}=$ caudal field

anterior to the fully developed ctenii was reduced in size. These abnormalities were observed in G. cernua and P. fluviatilis (Figs. 6A-6C).

- Disconnected radii were observed in scales of P. fluviatilis only (Fig. 6D).

- Presence of two loci. In this unusual abnormality, which was only observed in S. lucioperca, the circuli in the focus area were surrounded by two foci (Fig. 6E)

- Deformities in the corners of the scale. In this abnormality, which was observed in L. idus only, the corners of the scales were rounded rather than triangular (Fig. 6F).

Both body and lateral line scales exhibited ten cases of severe anomalies, including:

- Twin scales ("Siamese scales"). This type of anomaly was observed in lateral line scales of $H$. nobilis and body scales of $S$. lucioperca. The twin scales can be described as follows: the abnormal scales were fused in pairs, with two well developed foci instead of one. The appearance of these scales was completely different from normal scales. Both foci were displaced to the posterior field of the scale and situated at the same level. They were circular in shape and bounded by a complete concentric circulum. In the twin body scale of $S$. lucioperca the circulus around the focus was irregular and discontinued, while that from the lateral line area in $H$. nobilis was normal. In both cases the twin scales had the anterior part of the posterior field of the right scale fused to the dorsal part of the posterior field of the left scale (Figs. 6G and 6H).

- Displaced ctenii area. This type of anomaly was observed in two body scales of G. cernua. In one of these scales, part of the ctenii area was displaced posteriorly and dorsally. In the latter displaced area, the circuli were widely spaced. A slight deformity of the circuli was also noticed in the anterior ventral corner of this scale. The 
A

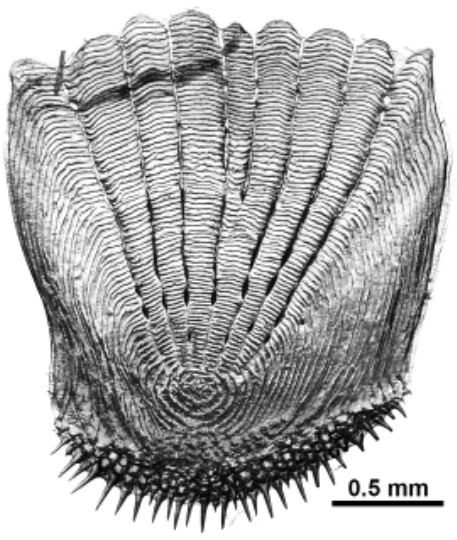

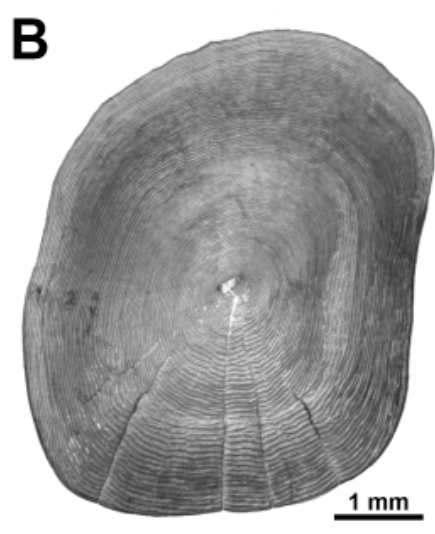

B
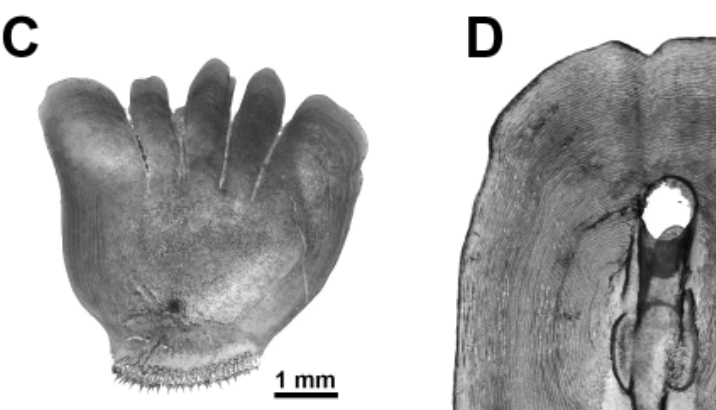

F
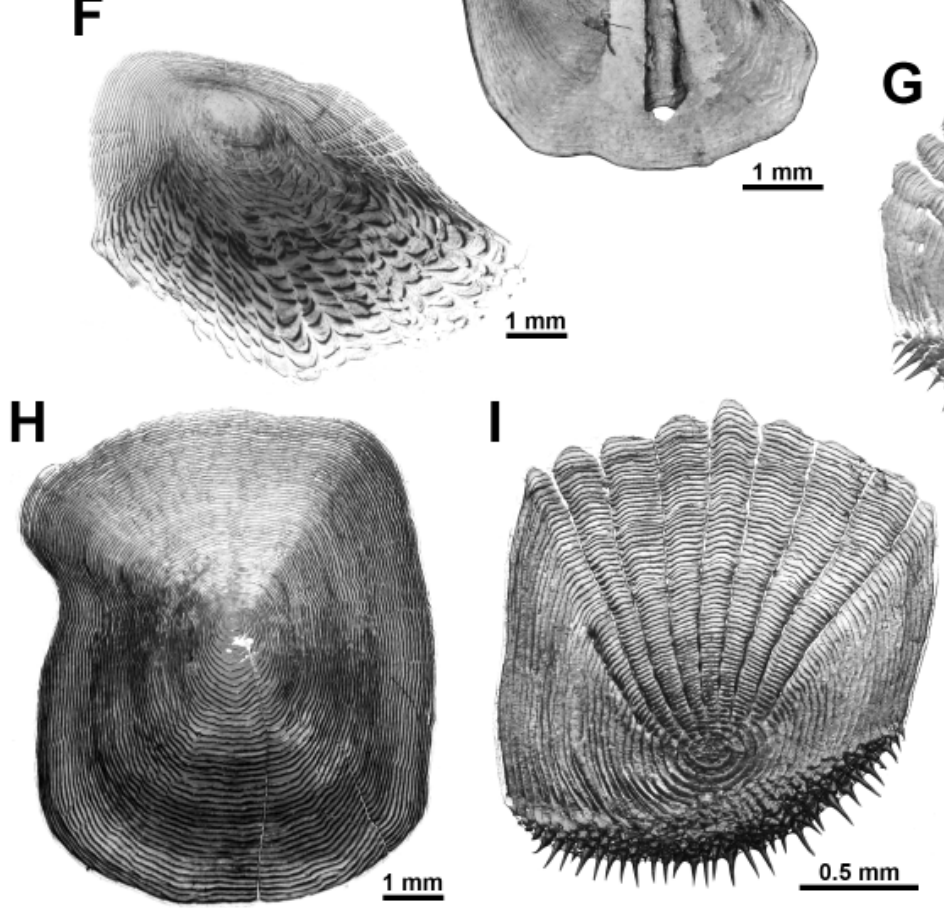

E

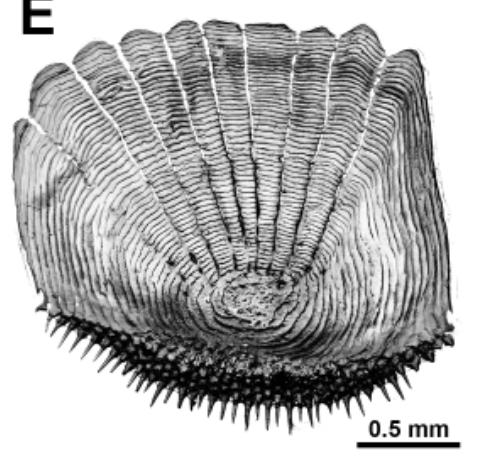

G
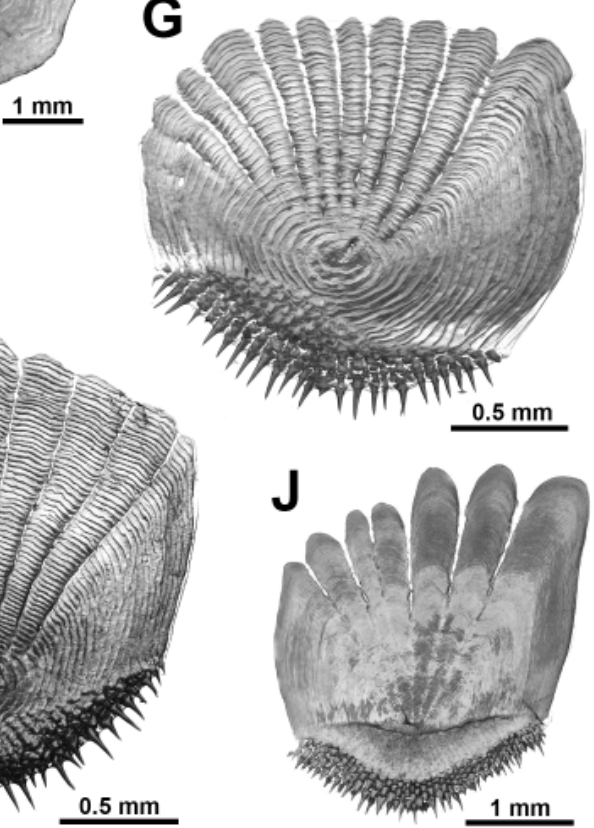

Fig. 5. Common abnormality cases: Abnormalities on dorsal and ventral sides of the scale (A-E); Displacement of the anterior and posterior end of the scale $(\mathbf{F}-\mathbf{H})$; Deformity of the lobes on the anterior side of the scales (I); Anomalies in scale circuli $(\mathbf{J})$

focus appeared to be normal in both shape and position. In the other scale, different segments appeared to have been attached to the posterior dorsal corner. The pattern of the circuli in this segment did not match that in the dorsal field of the scale. In addition, there was a complete deformation of the lobes in the anterior dorsal corner. The focus was tilted posteriorly (Figs. 7A and 7B).
- Indented scale. This anomaly was observed in a degenerated body scale of $P$. fluviatilis. The anterior part of the dorsal side of the scale was severely indented. The circuli in this area had an irregular shape around the degenerated focus. Other deformities associated with this indentation were a reduction in number of ctenii, 

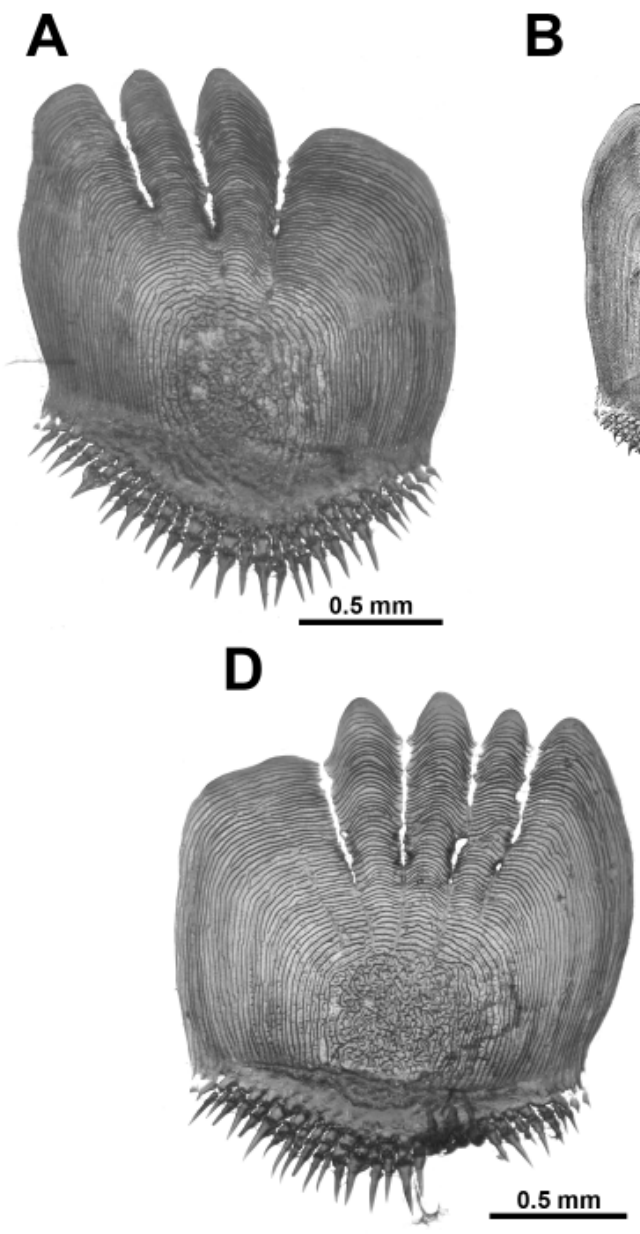

$\mathbf{F}$

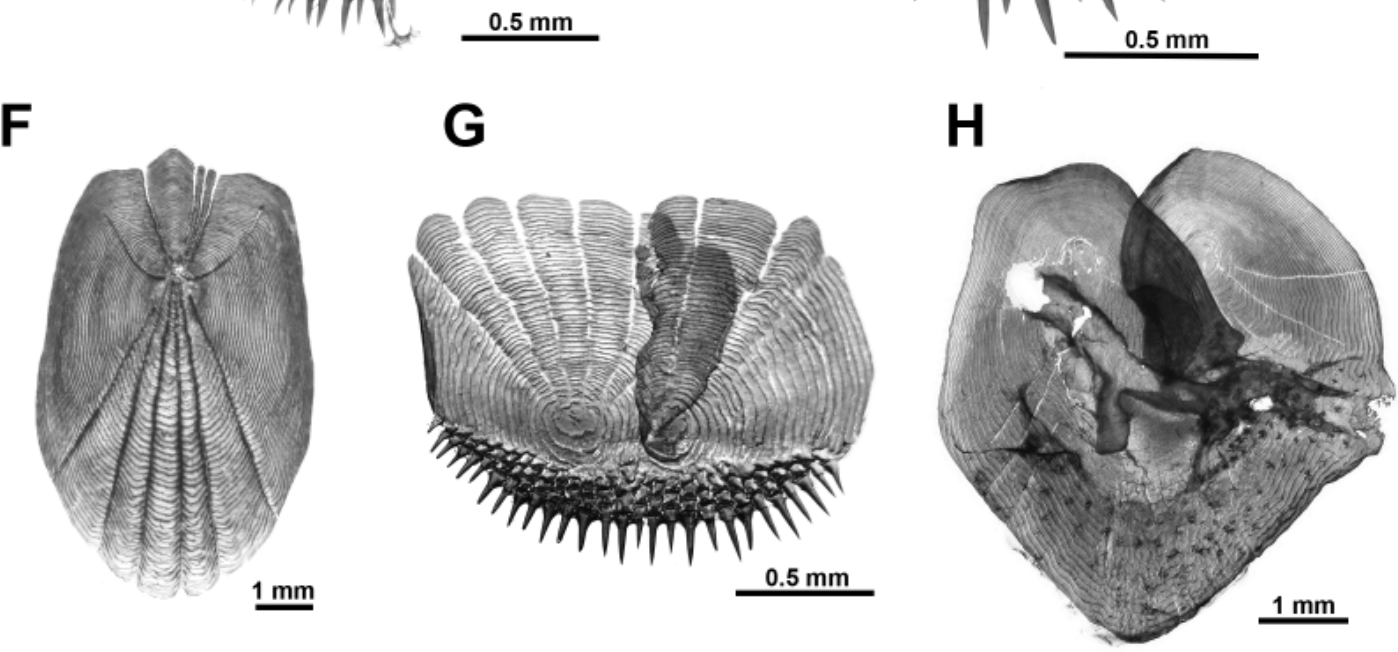

B

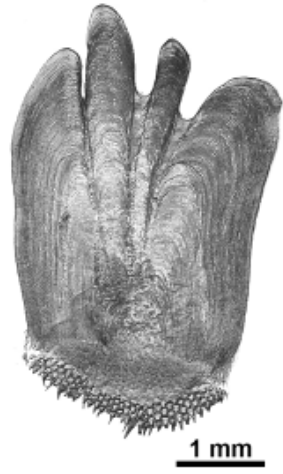

C

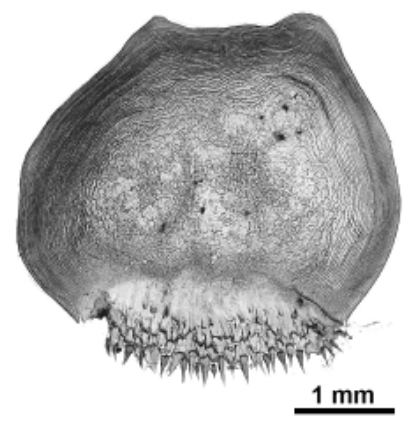

E

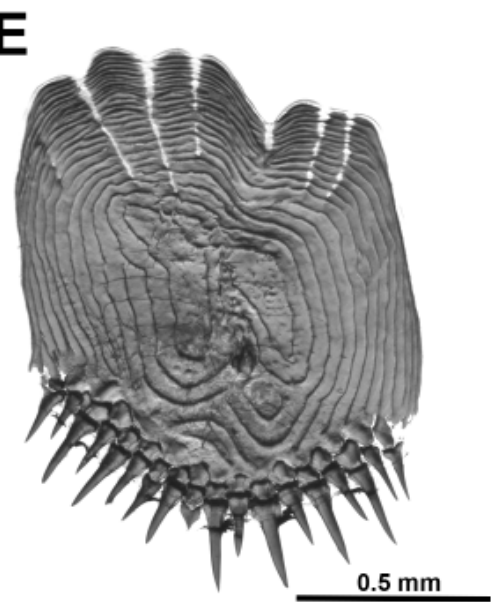

Fig. 6. Uncommon cases of scale abnormalities: Deformities of ctenii and the ctenii area (A-C); Disconnected radii (D); Presence of two loci (E); Deformities in the corners of the scale (F); Severe abnormality, Twin scales "Siamese scales" (G and $\mathbf{H})$

only two rows of ctenii remained, and deformation of the lobes at the anterior side of the scale (Fig. 7C).

- Overlapping scales. This abnormality was observed in two body scales of $P$. fluviatilis. Both scales overlapped so that the anterior side of the upper scale was tilted anterior-dorsally. The focus of the lower scale was degenerated, while that of the upper scale was normal.
The ctenii areas of both scales were mixed together, resulting in an irregular shape of the ctenii area. The lobes of the anterior side of the upper scale were normal, while those of the lower scale were deformed. The other scale showed similar deformities in addition to a severe deformity of the lobes of the anterior side of the lower scale (Fig. 7D). 


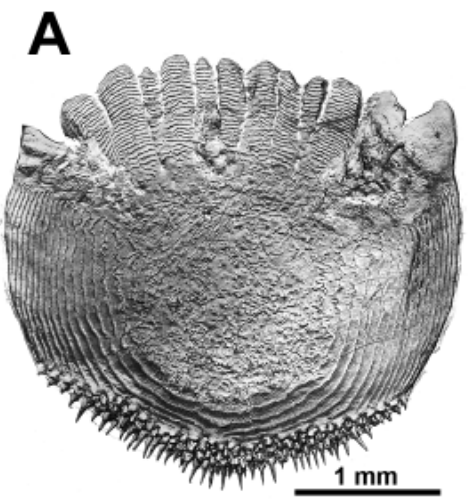

D
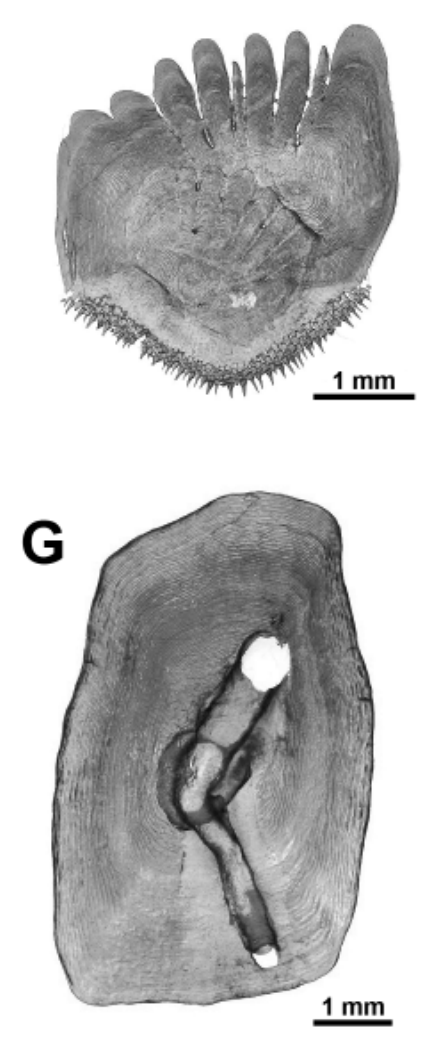

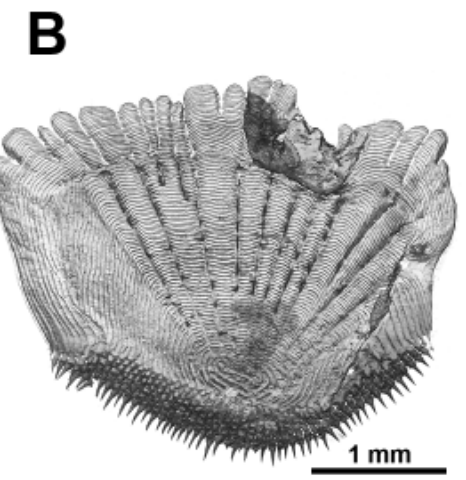

C

E
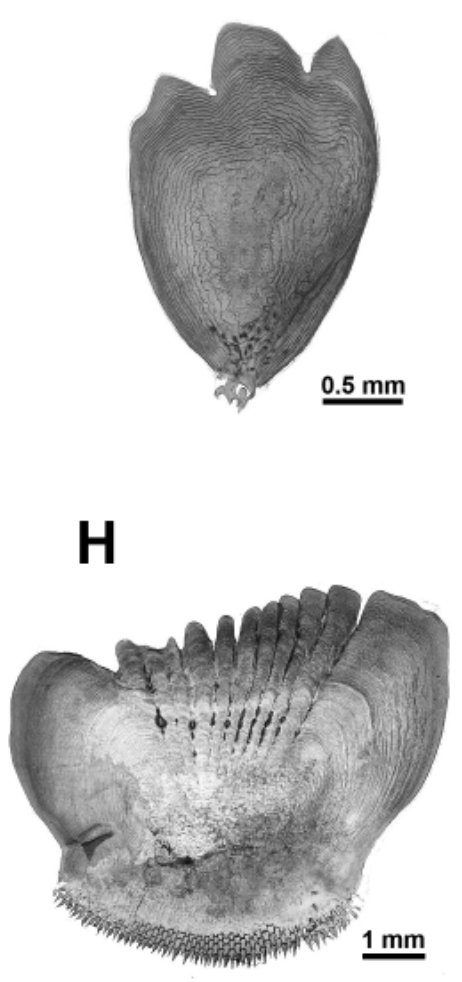

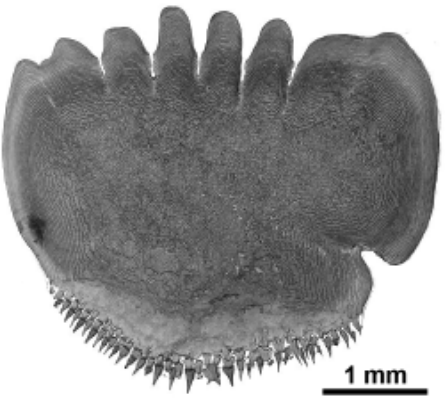

$\mathbf{F}$

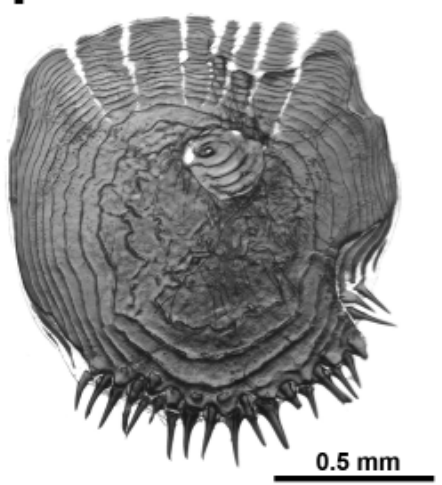

I

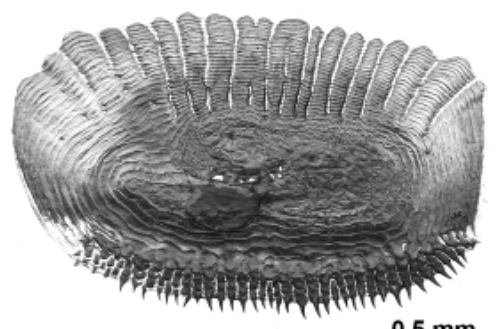

Fig. 7. Severe abnormalities: Displaced ctenii area (A and B); Indented scale (C); Overlapping scales (D); Pear-shape deformity (E); Displaced posterior field area (F); Lateral line canal deformity (G); Posterior field deformity $(\mathbf{H})$; Degenerated focus deformity (I)

- Pear-shape deformity. The scale in this type of anomaly was pear-shaped, and was observed in a degenerated body scale of $P$. fluviatilis. Both the ctenii area and the number of ctenii were reduced, with only two remaining deformed ctenii. The focus area and the circuli in the posterior field of the scale were oblong shaped. In the anterior field, the circuli were widely separated, disconnected and irregular. The lobes at the anterior side of the scale were deformed (Fig. 7E).

- Displaced posterior field area. A segment/part of the posterior area was observed posterior to the lobes at the anterior field area. This segment contained four widely spaced circuli and part of what looked like a piece of a normal focus. A strong indentation was observed at the posterior-dorsal corner where the dorsal end of the ctenii was present. This invagination in the wall of the scale caused damage to both the circuli and the ctenii in this area. This anomaly was observed in a degenerated body scale of $S$. lucioperca. The focus area was bounded by widely separated, disconnected and irregular circuli (Fig. 7F).

- Lateral line canal deformity. In this type of abnormality, the lateral line canal was observed to have one two bends either in the middle or in the anterior part of the canal. No radii were present. This anomaly was observed in a lateral line scale of $H$. nobilis (Fig. 7G).

- Posterior field deformity. In this type of abnormality, the posterior field was severely deformed, affecting the ctenii area and reducing the number of ctenii. It also resulted in the circuli being widely spaced. In another 
scale, the posterior field was constricted to the extent that it deformed the circuli in this area, the ctenii area was also affected. This abnormality was observed in scales of G. cernua and P. fluviatilis (Fig. 7H).

- Degenerated focus deformity. The area of the degenerated focus was filled with bumps of different sizes and shapes. Accordingly, the circuli in this area were badly affected. This abnormality was observed in G. cernua (Fig. 7I).

\section{DISCUSSION}

Sixty-three cases of abnormal scales were studied in the present paper (Figs. 4-7), whereby severe cases were slightly more represented than slight cases. Among the species studied, Sander lucioperca exhibited more severe abnormal scales than slight ones. This may indicate that the species was affected by more environmental factors that had a negative impact on the development of its scales than other species. Among those species commonly exhibiting slight cases of scale anomalies, Gymnocephalus cernua and Perca fluviatilis were more noticeable.

Although the number of specimens exhibiting scale anomalies was relatively small, they demonstrated a wide range of both slight and severe cases. P. fluviatilis exhibited the highest number of cases, while Ctenopharyngodon idella and Leuciscus idus exhibited the lowest, with only one case each.

The regenerated scales resembled ontogenetic scales but differed in superficial ornamentations where previous growth marks had disappeared (Neave 1940, Sire unpublished*). As in other teleosts (Meunier 2002), the abnormally regenerated scales observed in the presently reported study, exhibited a trend in increase of size which was related to fish size. Several shapes of regenerated scales were observed that were similar to those observed in ontogenetic scales (Figs. 5C, 6A, 6C, 6D, 7A, 7C, 7E, and $7 \mathrm{~F}$ ). Irregular scale shape was a dominant feature amongst the regenerated scales obtained from different body regions of the seven species studied. Scale loss is a common feature amongst fish exposed to accidental damage and this usually leads to the development of regenerated scales (Miranda and Escala 2002, Ashley 2007, Sfakianakis et al. 2013). Abnormally regenerated scales were observed in the percids (G. cernua, P. fluviatilis, and $S$. lucioperca) only, with the highest numbers observed in body regions 6,3 , and 8 , respectively. This may indicate that these species have a higher vulnerability of these body regions to accidents, as compared to other body regions. Previously published descriptions of the shape and size of regenerated scales (Quilhac and Sire 1998) equate with the different shapes and sizes of anomalous scales observed in the presently reported study. Deviations from the normal scale shape are due to compensatory growth which is an intrinsic factor (Ibáñez et al. 2012). Such events are associated with availability and type of food, which are, in turn, related to differences in extrinsic environmental driving factors (Swain and Foote 1999). The shape and size of the anomalous scales appeared to be affected during development. For regenerated scales, the size and shape depends on the location of the scales along the wound margins (Quilhac and Sire 1998). Scales located near the margin of the wound are larger than those near its centre. Quilhac and Sire (1998) noted that the shape of regenerated scales varied relative to the location of the wound. Marginally regenerated scales may be dorsoventrally (elongated) or anteroposteriorly (rectangular) asymmetrical, while those near the centre of the wound are more developed and look like normal scales. Irregularly shaped scales might also be due to the presence of two scales in one pocket, e.g., in our study the scale of $P$. fluviatilis obtained from body region 1 had two foci (Fig. $6 \mathrm{E}$ ).

The most interesting case in the presently reported study was the occurrence of twin or Siamese scales that were observed on the body and lateral line of Hypophthalmichthys nobilis (region 9) and Sander luciperca (region 4), respectively (Figs. $6 \mathrm{G}$ and $6 \mathrm{H}$ ). It is interesting to note that Quilhac and Sire (1998) observed that two scales could develop in the same pocket. However, Mookerjee (1948) suggested that arrested growth and other developmental irregularities might also contribute to this type of scale abnormality. The scales observed by Mookerjee (1948) were elongated with a complete margin. Despite the fusion, the development of ornamentations on the two scales proceeded in a normal way albeit the left scale was incomplete. The Siamese scales observed in the presently reported study looked exactly like those obtained by Jawad (2005c) in Oreochromis niloticus in Sudan. In both cases, the scales were joined at their caudal field but were free at their rostral fields. However, the latter scales differed from those obtained by Jawad and Al-Jufaili (2007) and Jawad et al. (2006) in having their rostral ends free and joined with their caudal ends.

The other interesting case of abnormal scales was observed in body region 1 of $P$. fluviatilis, which looked as if two scales overlapped (Fig. 7D). A similar case of scale abnormality was reported by Sire (1986), who suggested that a partial regeneration, following a wound, might have caused the anomaly.

Spines at the ctenial area and the subctenial area can be deformed due to degeneration (Hughes 1981) or amputation and resorption (Coburn and Gaglione 1992). Degeneration can occur following the continuous removal of the outer layers of the spines. Although amputation and resorption do not occur simultaneously, in some fish groups, such as the Percidae (see Coburn and Gaglione 1992), they found in places where a new row of ctenii is required to grow. In such an area, resorption of the amputated ctenii can occur. It is interesting to note that in the presently reported study, slight and severe cases of anomalous ctenii, subcteni and subctenial areas were observed in the scales of $P$. fluviatilis and S. lucioperca (Figs. 6A-6C ). Sire and Géraudie (1983) suggested that in the focus of the regenerated scales of Hemichromis bimaculatus Gill, 1862, the first step in the regeneration process was characterized by a pattern of tubercles of

* Sire J.-Y. 1987. Structure, formation et regeneration des ecailles d'un poisson teleosteen, Hemichromis bimaculatus (Perciforme, Cichlidae). These de Doctorate es-Sciences, Universite de Paris VII, Paris. 
various sizes forming ridges. This hypothesis may explain the case of the regenerated scale observed in region 2 of G. cernua, where tubercles of different shapes and sizes were observed in its regenerated focus.

Resorption of the calcified layer in teleost fish is due to the presence of mono- and multinucleated osteoclasts (Ouchi et al. 1972, Bigler 1989, Sire et al. 1990). Resorption usually takes place during periods of increased demand for calcium such as during sexual maturation (Persson et al. 1999). In the process of resorption, several scale micro-structures may be damaged, e.g., the circuli and radii. In their work on the scale osteoclasts of the rainbow trout, Oncorhynchus mykiss (Walbaum, 1792), during sexual maturation, Persson et al. (1999) observed a significant area of resorption on the scale surface, where circuli and radii were deformed and became irregular in their circularity around the focus or discontinued. It is interesting to note that similar deformities were observed in the scales obtained from several fish species in the presently reported study (Fig. 5J).

Common cases of scale abnormalities described in the presently reported study were observed in 3 species. This suggests that all of these species were subjected to similar causes of these anomalies. On the other hand, the uncommon and the severe cases of deformities reported here were found in fewer than 3 species which suggests that the causative agent(s) may have been more specific.

All species studied are considered native and with natural reproduction in the lakes where they were collected, except for $H$. molitrix, $H$. nobilis, and $C$. idella, which are considered non-native and do not reproduce naturally in their environment (Lusk et al. 2010a, 2010b). The source of the scale abnormalities in the native species has to be sought in these lakes, because the fish hatch and develop locally. Hypophthalmichthys molitrix, H. nobilis, and $C$. idella reproduce in aquaria only whereupon the fries are transported to the lakes for further development (L. Hanel, personal communication). At the age of their transportation, the scales have not fully developed, they were in their early stages. Therefore, any abnormalities that these scales might show after full development, will be due to the environmental factors of the lakes that they were transplanted to during their early life stages.

Corrales et al. (2000) suggested four main causes of scale abnormalities in fish: genetic disorders, disease, physical, and/or chemical environmental variables. It is impossible at this stage to investigate the possible genetic and pathogenic (including parasites) causes of the fish scale anomalies described here. Small founding populations of the stocked non-native species could possibly lead to developmental instabilities as a consequence of inbreeding, but this is highly speculative and, moreover, the occurrence of scale abnormalities in several native species suggests that the effect might be environmental rather than genetic (Browder et al. 1993). Physical and/ or chemical environmental variables are feasible causes. Environmental stress, such as overpopulation or poor water quality, have previously been suggested to have a negative influence on the developmental stability in pond reared cyprinids (Almeida et al. 2008). The chemical environmental variables were fairly well documented in the freshwater systems of the Czech Republic. High levels of certain pollutants recorded from the study area (Všetičkova et al. 2012) might have a direct effect during the developmental stages. Other pollutant sources in the area include thermal effluents from power stations (Vassolo and Döll 2005, Pavlas et al. 2006), wastewater treatment plants (Heteša et al. 2002), solid waste (Modrá and Svobdová 2009), and recreation and tourism facilities (Geneletti and Dawa 2009, Navrátil et al. 2011). The main pollutants present in the studied ponds include heavy metals and hydrocarbon contaminants (Kopicová and Vavreinová 2007), and organic pollutants (Pechar 2000, Nhan et al. 2006). Several authors have considered scales as potential bioindicators of pollution (Johal and Tandon 1989, Tandon and Johal 1993, Johal and Dua 1994). Johal and Dua (1994) noted that sudden changes in the environment could cause alterations in both the shape of the circuli and the pattern of elemental deposition in scales. Rishi and Jain (1998) suggested that cadmium toxicity could have a significant effect on the surface structures of scales such as on circuli and lepidonts. Therefore, it is quite possible that one or more of the pollutants mentioned above plays a significant role in producing the observed scale abnormalities. However, conclusive causes of the scale anomalies described in the presently reported study cannot be determined due to the lack of information on potential causal factors other than chemical variables. Further studies are clearly required and they should focus on the question whether or not the removal of abnormal scales will lead to replacement by either normal or abnormal scales. Studies on this issue, including the frequency of occurrence of abnormal scales in relation to environmental contaminants and physical stressors, should provide insights into the factors causing the observed abnormalities.

\section{ACKNOWLEDGEMENTS}

We are deeply indebted to Mrs Lenka Vybíralová of Vondroušova, Praha, Czech Republic for giving her permission to use Figs. 1 and 2 of Ctenopharyngodon idella and Gymnocephalus cernua drawn by her (permission was given to use this image free of charge for the purpose of this publication) and to Kristiaan Hoedemakers, Royal Belgian Institute of Natural Sciences, for corrections and improvements of the text.

\section{REFERENCES}

Almeida D., Almodóvar A., Nicola G.G., Elvira B. 2008. Fluctuating asymmetry, abnormalities and parasitism, as indicators of environmental stress in cultured stocks of goldfish and carp. Aquaculture 279 (1-4): 120-125. DOI: $10.1016 /$ j.aquaculture.2008.04.003

Ashley P.J. 2007. Fish welfare: Current issues in aquaculture. Applied Animal Behaviour Science 104 (3-4): 199-235.

DOI: 10.1016/j.applanim.2006.09.001 
Bengtsson B.-E., Coombs T.L., Waldichuk M. 1979. Biological variables, especially skeletal deformities in fish, for monitoring marine pollution [and discussion]. Philosophical Transactions of the Royal Society of London B 286 (1015): 457-464.

DOI: $10.1098 /$ rstb. 1979.0040

Bereiter-Hahn J., Zylberberg L. 1993. Regeneration of teleost fish scale. Comparative Biochemistry and Physiology, Part A: Physiology 105 (4): 625-641.

DOI: 10.1016/0300-9629(93)90262-3

Bigler B. 1989. Mechanism and occurrence of focal scale resorption among chum salmon, (Oncorhynchus keta) of the North Pacific Ocean. Canadian Journal of Fisheries and Aquatic Sciences 46 (7): 1147-1153. DOI: $10.1139 /$ f89-149

Blair A.A. 1942. Regeneration of the scales of Atlantic salmon. Journal of the Fisheries Research Board of Canada 5c (5): 440-447. DOI: $10.1139 /$ f40-045

Browder J.A., McClellan D.B., Harper D.E., Kandrashoff M.G., Kandrashoff W. 1993. A major developmental defect observed in several Biscayne Bay, Florida, fish species. Environmental Biology of Fishes 37 (2): 181-188. DOI: $10.1007 / \mathrm{BF} 00000593$

Coburn M.M., Gaglione J.I. 1992. A comparative study of percid scales (Teleostei: Perciformes). Copeia 1992 (4): 986-1001.

DOI: $10.2307 / 1446628$

Corrales J., Baribeau N.L.B., Gassman N.J., Scmale C. 2000. Characterization of scale abnormalities in pinfish, Lagodon rhomboids from Biscayne Bay, Florida. Environmental Biology of Fishes 57 (2): 205-220. DOI: $10.1023 / \mathrm{A}: 1007527424242$

Divanach P., Boglione C., Menu B., Koumoudouros G., Cataudella S. 1996. Abnormalities in finfish mariculture: An overview of the problem, causes and solutions. Pp. 134-154. In: Chantain B., Saroglia M., Sweetman J., Lavens P. (eds.) Seabass and seabream culture: Problem and prospects handbook of contributions and short communications presented at the International workshop on "Sea bass and sea bream culture: problems and prospects", Verona, Italy, 16-18 October 1996. European Aquacultural Society, Oostende, Belgium.

Fouda M.M. 1979. Studies on scale structure in the common goby Pomatoschistus microps Krøyer. Journal of Fish Biology 15 (2): 173-183. DOI: $10.1111 /$ j.1095-8649.1979.tb03581.x

Geneletti D., Dawa D. 2009. Environmental impact assessment of mountain tourism in developing regions: A study in Ladakh, Indian Himalaya. Environmental Impact Assessment Review 29 (4): 229-242.

DOI: 10.1016/j.eiar.2009.01.003

Günther G. 1941. A rare abnormality, a fish with reversed scales. Copeia 1941 (1): 176.

Günther G. 1945. Another redfish, Sciaenops ocellatus (Linnaeus) with reversed scales. Ichthyological Notes 1: 55 .
Günther G. 1948. A discussion of abnormal scale patterns in fishes, with notice of another specimen with reversed scales. Copeia 1948 (2): 280-285.

DOI: $10.2307 / 1438717$

Guilherme S., Válega M., Pereira M.E., Santos M.A., Pacheco M. 2008. Erythrocytic nuclear abnormalities in wild and caged fish (Liza aurata) along an environmental mercury contamination gradient. Ecotoxicology and Environment Safety 70 (3): 411-421.

DOI: $10.1016 /$ j.ecoenv.2007.08.016

Hanel H. 2003. The ichthyofauna of Czech Republic: Development and present state. Mathias Belivs University Proceeding, Banská Bystrica, Slovakia 3: 41-71.

Heteša J., Marvan P., Kupec P. 2002. Úvalský a Šibeník - rybníky suplující funkci čistíren odpadních vod. [Úvalský and Šibeník-ponds supplying the function of wastewater treatment plant.] Pp. 239-245. In: The 5th Czech Conference of Ichthyology; MZLU, Brno, Czech Republic. [In Czech with English summary.]

Hughes D.R. 1981. Development and organization of the posterior field of ctenoid scales in Platycephalidae. Copeia 1981 (3): 596-606. DOI: $10.2307 / 1444564$

Ibáñez A.L., Pacheco-Almanzar E., Cowx I.G. 2012. Does compensatory growth modify fish scale shape? Environmental Biology of Fishes 94 (2): 477-482. DOI: $10.1007 / \mathrm{s} 10641-011-9962-4$

Jawad L.A. 2005a. Comparative scale morphology and squamation patterns in triplefins (Pisces: Teleostei: Perciformes: Tripterygiidae). Tuhinga 16 (1): 137-168.

Jawad L.A. 2005b. Comparative morphology of scales of four teleost fishes from Sudan and Yemen. Journal of Natural History 39 (28): 2643-2660. DOI: $10.1080 / 00222930500102801$

Jawad L.A. 2005c. Scale deformities in Nile tilapia, Oreochromis niloticus (Actinopterygii: Cichlidae) from Sudan. Acta Ichthyologica et Piscatoria 35 (1): 61-63. DOI: 10.3750/AIP2005.35.1.08

Jawad L.A. 2008. Second revision of the New Zealand triplefin genus Forsterygion Whitley and Phillips, 1939 (Pisces: Tripterygiidae). Journal of Natural History 42 (47-48): 2943-2989.

DOI: $10.1080 / 00222930802256842$

Jawad L.A. 2014. Vertebral abnormalities in the oriental sole Brachirus orientalis (Bloch \& Schneider, 1801) (Teleostei, Hetrosomata) collected from the coasts of Muscat City on the Sea of Oman. Bollettino del Museo Civico di Storia Naturale di Verona, Botanica Zoologia 38 (1): 193-196.

Jawad L.A., Ahyong S.T., Hosie A. 2006. Malformation of the lateral line and ambicolouration in the triplefin Grahamina capito (Jenyns, 1842) (Pisces: Tripterygiidae) from New Zealand. Annali del Museo Civico di Storia Naturale di Ferrara 9-10 (1): 89-97.

Jawad L.A., Al-Jufaili S. 2007. Scale morphology of greater lizardfish, Saurida tumbil (Bloch, 1795) 
(Pisces: Synodontidae). Journal of Fish Biology 70 (4): 1185-1212.

DOI: $10.1111 / \mathrm{j} .1095-8649.2007 .01385 . \mathrm{x}$

Jawad L.A., AL-Mamry J.M. 2011. Scale deformities in rohu Labeo rohita (Osteichthyes: Cyprinidae). Annales: Series Historia Naturalis 21 (2): 167-174.

Jawad L.A., Ibrahim M. 2014. A reported case of malpigmentation in the pearl spotted rabbitfish Siganus canaliculatus (Park, 1797) (Family: Siganidae) obtained from Jubail area, Arabian Gulf, Saudia Arabia. Bollettino del Museo Civico di Storia Naturale di Verona, Botanica Zoologia 38 (1): 189-192.

Jawad L.A., Liu J. 2015. First record of vertebral anomalies in some members of the genus Pampus (family: Stromateidae) collected from Guangdong, China and from the Kii Peninsula, Honshu Island, Japan. Marine Biodiversity Records 8: e110.

DOI: $10.1017 / \mathrm{S} 1755267215000913$

Johal M.S., Dua A. 1994. SEM study of scales of freshwater snakehead, Channa punctatus (Bloch) upon exposure to endosulfan. Bulletin of Environmental Contamination and Toxicology 52 (5): 718-721.

DOI: $10.1007 /$ BF00195493

Johal M.S., Tandon K.K. 1989. Age and growth of catla, Catla catla (Hamilton, 1822) from Rang Mahal (Rajasthan) India. Bangladesh Journal of Agriculture Research 14 (1): 135-150.

Kopicová Z., Vavreinová S. 2007. Occurrence of squalene and cholesterol in various species of Czech freshwater fish. Czech Journal of Food Science 25 (4): 195-201.

Kuusipalo L. 1998. Scale morphology in Malawian cichlids. Journal of Fish Biology 52 (4): 771-781. DOI: $10.1111 /$ j.1095-8649.1998.tb00819.x

Kuusipalo L. 2000. Evolutionary inferences from the scale morphology of Malawian cichlid fishes. Advances in Ecological Research 31: 377-397. DOI: $10.1016 / \mathrm{S} 0065-2504(00) 31020-0$

Lippitsch E. 1993. A phyletic study on lacustrine haplochromine fishes (Perciformes: Cichlidae) of East Africa, based on scale and squamation characters. Journal of Fish Biology 42 (6): 903-946. DOI: $10.1111 /$ j.1095-8649.1993.tb00399.x

Lusk S., Lusková V., Hanel L. 2010a. Alien fish species in the Czech Republic and their impact on the native fish fauna. Folia Zoologica 59 (1): 57-72.

Lusk S., Lusková V., Hanel L. 2010b. The list of alien species in the ichthyofauna of the Czech Republic. Russian Journal of Biological Invasions 1 (3): 172-175.

DOI: $10.1134 / \mathrm{S} 2075111710030057$

Meunier F. J. 2002. Scales: description, diversity and function. Pp. 58-64. In: Panfili J., de Pontual T.H., Troadec H., Wright P.J. (eds.) Manual of fish sclerochronology IFREMER, Brest, France.

Miranda R., Escala M. 2000. Morphological and biometric comparison of the scales of the barbels (Barbus Cuvier) of Spain. Journal of Morphology 245 (3): 196-205.

DOI: 10.1002/1097-4687(200009)245:3<196::AID-JMOR2>3.0.C0;2-7
Modrá H., Svobodová Z. 2009. Incidence of animal poisoning cases in the Czech Republic: Current situation. Interdisciplinary Toxicology 2 (2): 48-51. DOI: $10.2478 / \mathrm{v} 10102-009-0009-\mathrm{z}$

Mookerjee S. 1948. An atypical scale of Sciaena coiter (Hamilton). Nature 161 (4080): 64-65. DOI: $10.1038 / 161064 b 0$

Navrátil J., Pícha K., Rajchard J., Navrátilová J. 2011. Impact of visit on visitors' perceptions of the environments of nature-based tourism sites. Tourism 59 (1): 7-23.

Neave F. 1940. On the histology and regeneration of the teleost scale. Quarterly Journal of the Microscopical Society 81 (3): 541-568.

Nhan D.K., Milstein A., Verdegem M.C.J., Verreth J.A.V. 2006. Food inputs, water quality and nutrient accumulation in integrated pond systems: A multivariate approach. Aquaculture 261 (1): 160-173. DOI: 10.1016/j.aquaculture.2006.07.015

Ouchi K., Yamada J., Kosaka S. 1972. [On the resorption of scales and associated cells in the precocious male parr of the masu salmon (Oncorhynchus masou).] Bulletin of the Japanese Society of Scientific Fisheries 38 (5): 423-430. [In Japanese with English Summary.]

Parente T.E.M., De-Oliveira A.C.A.X., Silva I.B., Araujo F.G., Paumgartten F.J.R. 2004. Induced alkoxyresorufin- $O$-dealkylases in tilapias (Oreochromis niloticus) from Guandu River, Rio de Janeiro, Brazil. Chemosphere 54 (11): 1613-1618. DOI: $10.1016 /$ j.chemosphere.2003.09.027

Pavlas M., Stehlík P., Oral J, Šikula J. 2006. Integrating renewable sources of energy into an existing combined heat and power system. Energy 31 (13): 2499-2511. DOI: $10.1016 /$ j.energy.2005.11.003

Pechar L. 2000. Impacts of long-term changes in fishery management on the trophic level water quality in Czech fish ponds. Fisheries Management and Ecology 7 (1-2): 23-31.

DOI: $10.1046 / j .1365-2400.2000 .00193 . x$

Persson P., Björnsson B.T., Takagi Y. 1999. Characterization of morphology and physiological actions of scale osteoclasts in the rainbow trout. Journal of Fish Biology 54 (3): 669-684.

DOI: $10.1111 / \mathrm{j} .1095-8649.1999 . t b 00645 . \mathrm{x}$

Quilhac A., Sire J.-Y. 1998. Restoration of the subepidermal tissues and scale regeneration after wounding a cichlid fish, Hemichromis bimaculatus. The Journal of Experimental Zoology Part A 281 (4): 305-327.

DOI: 10.1002/(SICI)1097-010X(19980701)281:4<305::AID-JEZ6>3.0.C0;2-S

Rishi K.K., Jain M. 1998. Effect of toxicity of cadmium on scale morphology in Cyprinus carpio (Cyprinidae). Bulletin of the Environmental Contamination and Toxicology 60 (2): 323-328.

DOI: $10.1007 / \mathrm{s} 001289900629$

Roberts C.D. 1993. Comparative morphology of spined scales and their phylogenetic significance in the Teleostei. Bulletin of Marine Science 52 (1): 60-113. 
Sfakianakis D.G., Katharios P., Tsirigotakis N., Doxa C.K., Kentouri M. 2013. Lateral line deformities in wild and farmed sea bass (Dicentrarchus labrax, L.) and sea bream (Sparus aurata, L.). Journal of Applied Ichthyology 29 (5): 1015-1021.

DOI: $10.1111 /$ jai. 12248

Sindermann C.J. 1979. Pollution-associated diseases and abnormalities of fish and shellfish: A review. Fishery Bulletin 76 (4): 717-749.

Sire J.Y. 1986. Ontogenic development of surface ornamentation in the scales of Hemichromis bimaculatus (Cichlidae). Journal of Fish Biology 28 (6): 713-724.

DOI: 10.1111/j.1095-8649.1986.tb05205.x

Sire J.-Y., Boulekbache H., Joly C. 1990. Epidermaldermal and fibronectin cell-interactions during fish scale regeneration: Immunofluorescence and TEM studies. Biology of the Cell 68 (2): 147-158. DOI: 10.1016/0248-4900(90)90300-R

Sire J.-Y., Géraudie J. 1983. Fine structure of the developing scale in the cichlid, Hemichromis bimaculatus (Pisces, Teleostei, Perciformes). Acta Zoologica (Stockholm) 64 (1): 1-8.

DOI: 10.1111/j.1463-6395.1983.tb00635.X

Sun P.L., Hawkins W.E., Overstreet R.M., BrownPeterson N.J. 2009. Morphological deformities as biomarkers in fish from contaminated rivers in Taiwan. International Journal of Environmental Research and Public Health 6 (8): 2307-2331.

DOI: $10.3390 /$ ijerph6082307

Swain D.P., Foote C.J. 1999. Stocks and chameleons: The use of phenotypic variation in stock identification. Fisheries Research 43 (1-3): 113-128. DOI: 10.1016/S0165-7836(99)00069-7
Takagi K. 1953. A study on the scale of the gobiid fishes of Japan. Journal of the Tokyo University of Fisheries 39 (2): 231-253.

Taki I. 1938. On the abnormal arrangement of scales and colour bands in a sole (Zebrias), with special reference to its adverse scales. Journal of Science Hiroshima University B 6 (1): 1-14.

Tandon K.K., Johal S. 1993. Growth parameters of an endangered fish species-golden mahseer. Tor putitora (Hamilton) from Gobindsagar. Pp. 207-220. In: Sigh H.R. (ed.) Advances in limnology. Narendra Publishing House, New Delhi, India.

Tyler J.C., Johnson G.D., Jawad L.A., Brothers E.B. 2014. A developmentally "tail-less" adult cowfish, Lactoria cornuta, from Oman (Ostraciidae, Tetraodontiformes). Proceedings of the Biological Society of Washington 127 (2): 311-322. DOI: 10.2988/0006-324X-127.2.311

Vassolo S., Döll P. 2005. Global-scale gridded estimates of thermoelectric power and manufacturing water use. Water Resources Research 41 (4): 1-11. DOI: 10.1029/2004WR003360

Všetičkova L., Adámek Z., Rozkošný M., Sedláček P. 2012. Effects of semi-intensive carp pond farming on discharged water quality. Acta Ichthyologica et Piscatoria 42 (3): 223-231.

DOI: 10.3750/AIP2011.42.3.06

Yamada J. 1961. Studies on the structure and growth of the scales in the goldfish. Memoirs of the Faculty of Fisheries Hokkaido University 9 (2): 181-226.

Received: 26 May 2016 Accepted: 24 September 2016 Published electronically: 30 September 2016 